\title{
Analisis Karakteristik Stimulus dan Level Kognitif Soal UM-PTKIN Tahun 2019
}

\author{
Hasriani Umar \\ SMP Negeri 2 Palopo \\ Email: hasriani_anie@iainpalopo.ac.id
}

\begin{abstract}
PTKIN plays a role in improving human resources, so a selection system is needed which can select students according to their competence. UM-PTKIN is one of a system for selecting prospective students. In the selection system, the questions being tested require the ability to think from low to a high level of prospective students so that knowing the characteristics of the questions being tested is one of the keys to the success of prospective students in facing selection. This study aims to classify the characteristics of the UM-PTKIN questions based on the form of the question stimulus and the cognitive level of the questions based on the revised Bloom 's Taxonomy. This type of research is qualitative research using content or document analysis techniques based on the characteristics of the stimulus and the cognitive level of questions. The data collection techniques in this study used non-test techniques and focus group discussion (FGD) using questionnaires and FGD guidelines. The results showed 1) mathematics questions on UM-PTKIN basic ability test in 2019 with the 1911 script code contains 3 questions in the form of image stimulus, 1 question in the form of graphical stimulus and tables, 3 questions in the form of stimulus formulas, 2 questions in the form of stimulus for mathematical equations, 4 questions in the form of stimulus examples and 13 questions in the form of case fragment stimulus; 2) The questions contained $26 \%$ in the LOTS question category, 30\% with the MOST question category and $44 \%$ with the HOTS question category with the overall distribution of the question material, the material of the flat shape was the material that appears the most.
\end{abstract}

Keywords: cognitive level; mathematics; stimulus; test; UM-PTKIN

\begin{abstract}
Abstrak
PTKIN berperan dalam peningkatan sumber daya manusia sehingga dibutuhkan sistem seleksi yang menyaring mahasiswa sesuai kompetensinya. UM-PTKIN merupakan salah satu sistem seleksi calon mahasiswa. Dalam sistem seleksi, soal-soal yang diujikan menuntut kemampuan berpikir calon mahasiswa baik level rendah hingga tingkat tinggi sehingga mengetahui karakteristik soal yang diujikan menjadi salah satu kunci keberhasilan calon mahasiswa menghadapi seleksi. Penelitian ini bertujuan untuk mengklasifikasikan karakteristik soal UM-PTKAIN berdasarkan bentuk stimulus soal serta level kognitif soal berdasarkan Taksonomi Bloom revisi. Jenis penelitian ini yakni penelitian kualitatif menggunakan teknik analisis isi atau dokumen berdasarkan karakteristik stimulus dan level kognitif soal. Adapun teknik pengumpulan data pada penelitian ini menggunakan teknik non-tes dan focus group discussion (FGD) dengan menggunakan instrumen angket dan pedoman FGD. Hasil penelitian menunjukkan 1)
\end{abstract}


soal matematika pada tes kemampuan dasar UM-PTKIN tahun 2019 dengan kode naskah 1911 memuat 3 soal dengan bentuk stimulus gambar, 1 soal dengan bentuk stimulus grafik dan tabel, 3 soal dengan bentuk stimulus rumus, 2 soal dengan bentuk stimulus persamaan matematika, 4 soal dengan bentuk stimulus contoh serta 13 soal dengan bentuk stimulus penggalan kasus; 2) Soal memuat $26 \%$ dengan kategori soal LOTS, 30\% dengan kategori soal MOST dan 44\% dengan kategori soal HOTS dengan ketersebaran materi soal secara keseluruhan, materi bangun datar merupakan materi yang paling banyak muncul.

Kata kunci: level kognitif; matematika; soal; stimulus; UM-PTKAIN

\section{PENDAHULUAN}

Perguruan tinggi merupakan lembaga yang berperan dalam mencetak sumber daya manusia (SDM) yang berkualitas. Kualitas SDM bergantung pada lulusan yang dihasilkan, dimana lulusan mendapat tempat yang baik di dalam masyarakat dan dunia kerja yang sesuai dengan bidangnya. Sebagai tonggak awal untuk memperoleh lulusan yang berkualitas, kreatif, inovatif, serta berdaya saing diperlukan seleksi calon mahasiswa baru.

Seleksi penerimaan calon mahasiswa baru dilakukan untuk menyaring mahasiswa yang jumlah pendaftarnya terus meningkat dari tahun ke tahun hingga melahirkan lulusan yang berkualitas dan berkompeten dibidangnya. Santosa (2013) menyatakan bahwa hasil tes potensi akademik (TPA) yang dilakukan dalam seleksi calon mahasiswa berpengaruh terhadap kualitas lulusan. Senada dengan hal tersebut, Merwe dan Beer (2006) juga mengungkapkan bahwa tes potensi belajar memiliki kekuatan prediksi yang tinggi terhadap kemampuan kognitif dan kualitas lulusan, serta memprediksi kinerja akademis di masa depan.

Perguruan Tinggi Keagamaan Islam Negeri (PTKIN) yakni UIN/IAIN/STAIN sebagai salah satu penyelenggara pendidikan tidak terlepas dari seleksi penerimaan mahasiswa baru. Berdasarkan UU No. 12 Tahun 2012 tentang Pendidikan Tinggi dan Peraturan Pemerintah RI Nomor 4 Tahun 2014 tentang Penyelenggaraan Pendidikan Tinggi dan Pengelolaan Perguruan Tinggi, ditetapkan bahwa pola penerimaan mahasiswa baru dilingkup UIN/IAIN/STAIN di Indonesia dilakukan secara nasional yang disebut dengan Seleksi Prestasi Akademik Nasional Perguruan Tinggi Keagamaan Islam Negeri (SPAN-PTKIN) dan pola bentuk lain disebut Ujian Masuk Perguruan Tinggi Keagamaan Islam Negeri (UM-PTKIN).

Berdasarkan prosedur operasional baku UM-PTKIN tahun 2020, panitia nasional penerimaan mahasiswa baru mengembangkan tes melalui beberapa tahapan antara lain: 1) Pengembangan kerangka acuan kerja sebagai penetuan arah tahapan pengembangan tes sehingga target dapat tercapai; 2) Pengembangan dan penetapan kisi-kisi baik 
jumlah butir soal dan sebaran level kognitif yang masuk pada kategori higher order thinking (HOT); 3) Workshop penulisan yang bertujuan untuk meningkatkan keterampilan calon penulis soal dengan berpedoman pada kisi-kisi dan rambu-rambu pengembangan soal; 4) Penulisan soal sesuai dengan prinsip dan kisi-kisi yang sudah ditetapkan; 5) Penelaahan butir soal oleh tim internal dalam rangka peningkatan kualitas soal yang telah disusun dan merevisi butir soal atas dasar saran dari penulis-penulis lain; 6) Penelaahan butir soal dan perakitan paket tes oleh tim eksternal dari butir soal yang telah dihasilkan oleh tim penulis; 7) Penyelarasan Bahasa oleh tim ahli bahasa dengan mengacu pada tata Bahasa Indonesia yang untuk menghindari kemungkinan penggunaan bahasa yang kurang jelas, tidak baku, tidak efisien, dan bias makna; 8) Pengacakan soal untuk memperoleh paket soal; dan 9). Finalisasi yakni pemeriksaan lengkap terhadap semua paket soal untuk memastikan tidak ada kesalahan penulisan, jawaban, dan lay-out (setting) naskah soal.

Naskah soal UM-PTKIN terdiri dari butir-butir soal yang berdasarkan pengembangan dan penetapan kisi-kisi soal mencakup level kognitif yang masuk pada kategori higher order thinking skill (HOTS) atau kemampuan berpikir tingkat tinggi. HOTS meliputi kemampuan logika dan penalaran (logic and reasoning), analisis (analysis), evaluasi (evaluation), dan kreasi (creation), pemecahan masalah (problem solving), dan pengambilan keputusan (judgement) (Brookhart, 2010). Disamping itu, HOTS juga menuntut kemampuan berpikir yang tidak sekadar mengingat (recall), menyatakan kembali (restate), atau merujuk tanpa melakukan pengolahan (recite) (Widana, 2017).

Merujuk pada soal dan hasil belajar matematika di Indonesia, penelitian yang dilakukan oleh Yenusi, Mumu dan Tanujaya (2019) bahwa hanya terdapat sebagian kecil soal-soal latihan dalam buku teks matematika yang dapat dikelompokkan sebagai soal HOTS. Soal-soal HOTS tersebut, hanya berada pada dua kemampuan C4 dan C5 dan tidak ada satu butir soal latihan yang tergolong sebagai soal HOTS tersebut yang berada pada kemampuan C6. Selanjutnya, berdasarkan penelitian Witri dan Tambunan (2019), kemampuan peserta didik dalam mengerjakan soal-soal HOTS masih sangat rendah dimana pada kemampuan analisis berada kategori cukup, kemampuan mengevaluasi berada pada kategori sangat kurang dan pada kemampuan mencipta berada pada kategori sangat kurang.

Hasil di atas diperkuat oleh laporan PISA terbaru selasa 3 Desember 2019, diketahui kemampuan peserta didik Indonesia masih sangat rendah. Untuk skor matematika, Indonesia berada diperingkat 72 dari 78 negara. Dengan kata lain, Indonesia menduduki peringkat 6 kebawah dengan rata-rata penguasaan pelajaran peserta didik Indonesia hanya sampai level C3 atau kemampuan menerapkan. Hal ini 
membuktikan kurangnya kemampuan peserta didik di Indonesia dalam mengerjakan soal PISA yang menuntut kemampuan penalaran, kemampuan analisis, evaluasi, dan kreasi dalam pengerjaannya (Kurniati, Harimurti dan Jamil, 2016).

Pengembangan HOTS juga kini menjadi prioritas dalam pendidikan di Indonesia. Muhadjir Effendy (Kemendikbud, 2018) mengatakan bahwa pendidikan di Indonesia masih membutuhkan penguatan HOTS. Implementasi ini melibatkan banyak elemen yang terdapat dalam delapan standar nasional pendidikan (SNP), yang terdiri dari konten pembelajaran, metodologi, pembelajaran, guru, kesiapan peserta didik, dan sarana serta prasarana. Kemampuan ini akan tercapai apabila peserta didik dapat menguasai kemampuan pada setiap ranah kognitif.

Menurut Arifin (2013), ranah kognitif mencakup kemampuan peserta didik pada pengetahuan (knowledge) atau $\mathrm{C} 1$, pemahaman (comprehension) atau $\mathrm{C} 2$, penerapan (aplication) atau $\mathrm{C} 3$, analisis (analysis) atau $\mathrm{C} 4$, sintesis (syntesis) atau C5 dan evaluasi (evaluation) atau C6. Kemampuan C1 dan C2 merupakan level kognitif tingkat rendah, Kemampuan C3, C4, C5, dan C6 termasuk level kognitif tingkat tinggi. Serupa dengan itu, Anderson dan Krathwohl (2001) mengungkapkan bahwa ranah kognitif berdasarkan kerangka Taksonomi Bloom revisi, proses kognitif terbagi menjadi kemampuan berpikir tingkat rendah (Lower Order Thinking (LOT)) yang terdiri dari pengetahuan dan penerapan; kemampuan berpikir tingkat menengah (Middle Order Thingking Skills (MOTS)) terdiri dari memahami dan dan kemampuan berpikir tingkat tinggi (Higher Order Thinking Skill (HOTS)).

LOT meliputi kemampuan mengingat (remember) dan memahami (understand), MOTS terdiri dari kemampuan menerapkan (apply), sedangkan HOTS meliputi kemampuan menganalisis (analyze), mengevaluasi (evaluate), dan menciptakan (create). Penerapan HOTS pada soal mengharuskan peserta didik untuk dapat mentransfer konsep; memanipulasi, memproses, dan menerapkan serta mengaitkan informasi; menyelesaikan masalah dengan informasi tersebut; serta menelaah ide dan informasi secara kritis.

Soal HOTS merupakan instrumen pengukuran yang digunakan untuk mengukur kemampuan berpikir tingkat tinggi. Kakteristik soal meliputi aspek kemampuan untuk memecahkan masalah, berpikir kritis dan kreatif, kemampuan berargumen, dan kemampuan mengambil keputusan serta berbasis hal-hal yang bersifat kontekstual.

Ditinjau dari pelaksanaan seleksi UM-PTKIN yakni untuk mewujudkan sumber daya manusia yang berkualitas, maka diperlukan penataan dan inovasi pada aspek pendidikan termasuk adanya kemampuan berpikir tingkat tinggi dalam komponen soal. Peserta didik harus peka terhadap tipe-tipe soal yang tersedia dalam naskah soal UMPTKIN. Oleh karena itu, diperlukan analisa karakteristik soal matematika UM-PTKIN 
untuk memberikan gambaran bagi peserta didik berbagai tipe-tipe soal yang muncul serta bekal bagi guru untuk senantiasa menyusun dan memberikan soal-soal latihan yang setipe UM-PTKIN dalam pelaksanaan penilaian harian maupun soal try out atau latihan dalam menghadapi UN dan seleksi pada perguruan tinggi.

\section{METODE}

Penelitian ini merupakan penelitian kualitatif jenis analisis atau dokumen. Analisis isi merupakan metode penelitian yang digunakan untuk menghimpun, membahas serta menganalisis secara detail dokumen atau suatu informasi tertulis atau tercetak dalam suatu media. Weber (Moleong, 2007) menyatakan bahwa analisis isi merupakan seperangkat prosedur dalam metodologi penelitian untuk menarik simpulan yang sahih dari sebuah buku atau dokumen. Jadi analisi isi bertujuan untuk menghimpun, memahami, menganalisis, serta mendeskripsikan informasi yang tersedia dari dokumen.

Informasi yang dimaksud dalam penelitian ini yakni mengidentifikasi karakteristik butir soal berdasarkan pertanyaan atau stimulus yang ada pada naskah soal. Stimulus berbentuk sumber/bahan bacaan seperti teks paragraf, rangkaian kasus, gambar, grafik, foto, rumus, tabel, daftar kata, simbol, contoh, peta, film, atau rekaman sebagai dasar dalam menyusun pertanyaan (Lailly dan Wisudawati, 2015). Selain itu, informasi tersebut, dalam penelitian ini juga mengidentifikasi karakteristik butir serta sebaran dimensi level kognitif pada soal matematika UM-PTKIN berdasarkan berdasarkan Taksonomi Bloom revisi dan ketersebaran soal berdasarkan materi.

Subjek dalam penelitian ini yakni soal matematika UM-PTKIN tahun 2019 tipe tes kemampuan dasar dengan kode naskah 1911. Kode naskah yang dipilih merupakan salah satu dari beberapa kode naskah tes kemampuan dasar yang tersedia dalam tes seleksi dimana soal yang di ujikan pada dasarnya sama hanya nomor soal yang menjadi perbedaan. Adapun teknik pengumpulan data pada penelitian ini menggunakan teknik non-tes dan Focus Group Discussion (FGD). Teknik non tes menggunakan triangulasi sumber yaitu mengumpulkan data dari empat sumber yang berbeda yakni peneliti, dua guru mata pelajaran matematika dari sekolah yang berbeda serta dosen program studi matematika. Tujuan dari pengumpulan data ini yakni untuk mendapatkan data primer hasi analisis dari sumber untuk selanjutnya direduksi dan digunakan sebagai pedoman dalam FGD. Sedangkan tujuan dari pelaksanaan FGD yaitu persamaan persepsi hingga didapatkan kesimpulan yang sama terkait analisis soal yang dibahas dalam penelitian ini. 
Instrumen yang digunakan dalam penelitian ini yaitu angket dan pedoman FGD. Angket dibuat berdasarkan karakteristik dasar pertanyaan dan level kognitif soal. Sedangkan pedoman FGD dibuat berdasarkan reduksi atau pengelompokan dari hasil analisis sumber.

\section{HASIL DAN PEMBAHASAN}

Berdasarkan hasil penelitian, diperoleh bahwa jumlah soal matematika yang terdapat dalam tes kemampuan dasar soal UM-PTKIN dengan kode naskah 1911 berjumlah 27 soal dari 110 soal. Soal tersebut terdiri dari 17 soal matematika tes potensi akademik dengan nomor soal 19 sampai 35 dan 10 soal matematika dasar dengan nomor soal 101 sampai dengan 110.

\section{Analisis Karakteristik Stimulus}

Stimulus merupakan langkah awal dalam menyusun suatu pertanyaan. Stimulus digunakan hendaknya menarik dan kontekstual sesuai dengan kenyataan dalam kehidupan sehari-hari. Kriteria stimulus yang baik dalam penyusunan soal menurut Priatna et al (2017) yaitu: (1) substantif dan memiliki daya tarik untuk dibaca; (2) menarik perhatian peserta didik; (3) ditulis dan didesain dengan baik, (4) tidak terlalu mudah dan juga terlalu sulit, namun cukup menantang untuk dikerjakan, (5) dikategorikan benar secara faktual, (6) dapat mengantar pada pertanyaan, dan (7) cerita utuh dan serba-cakup.

Hasil analisis soal matematika tes kemampuan dasar soal UM-PTKIN dengan kode naskah 1911 tahun 2019 berdasarkan karakteristik stimulus dapat dilihat pada tabel 1.

Tabel 1. Karaketristik Stimulus

\begin{tabular}{rlccc}
\hline \hline No & Bentuk Stimulus & Butir Soal & Jumlah & Persentasi \\
\hline \hline 1 & Gambar & $31,33,34$ & 3 & $11 \%$ \\
2 & Grafik & 32 & 1 & $4 \%$ \\
3 & Simbol & - & - & - \\
4 & Diagram & - & - & - \\
5 & Tabel & 106 & 1 & $4 \%$ \\
6 & Rumus & $21,105,109$ & 3 & $11 \%$ \\
7 & Persamaan Matematika & 25,27 & $7 \%$ \\
8 & Contoh & $24,26,28,101$ & 2 & $15 \%$ \\
9 & Penggalan & $19,20,22,23,29,30$, & 4 & $48 \%$ \\
& Kasus & $35,102,103,104,107$, & 13 & \\
\hline & & 108,110 & $\mathbf{1 0 0 \%}$ \\
\hline
\end{tabular}

Berdasarkan Tabel 1, stimulus yang digunakan pada soal terdiri 7 dari 9 bentuk stimulus. Bentuk stimulus sudah bervariasi namun kurang merata. Bentuk stimulus yang 
paling banyak muncul yakni penggalan kasus yang jumlahnya hingga 13 butir soal dan disusul oleh bentuk stimulus contoh sebanyak 4 butir soal.

Pada soal juga tidak terdapat karakteristik stimulus berupa simbol dan diagram. Stimulus berupa gambar terlihat jelas pada soal yakin nomor soal 31, 33, dan 34. Pada soal nomor 31 menunjukkan gambar lingkaran. Pada soal nomor 33 dan 34 terkait dengan bidang datar yakni persegi dan segitiga. Pada karakteristik stimulus berupa grafik yakni terdapat pada soal nomor 32. Soal menunjukkan grafik garis lurus dengan besar sudutnya.

Stimulus berupa tabel yakni berada pada soal no 106. Tabel merupakan daftar yang berisi rincian informasi baik yang berupa kata maupun angka yang dapat dilihat dengan jelas. Namun pada soal ini, informasi dalam tabel hanya sedikit. Data yang disajikan hanya terkait jumlah penjualan sarung. Jika diperhatikan lebih mendalam, stimulus pada soal lebih kepada penggalan kasus.

Karakteritik stimulus berupa rumus terdapat soal nomor 21,105 dan 109. Pada soal berturut-turut ditampilkan dengan jelas informasi mengenai rumus hubungan $x$ dan $y$, pengukuran pertumbuhan domba dengan rentang waktu tertentu serta volume suatu kotak. Matematika pada dasarnya tidak terlepas dari rumus, sehingga matematika diidentikkan sebagai pelajaran yang sangat sulit dan bersifat abstrak. Selain itu, soal pada matematika tidak terlepas dari bentuk persamaan. Karakteristik stimulus berupa persamaan matematika dapat dilihat pada contoh soal nomor 27. Pada soal sangat jelas memberikan informasi mengenai persamaan garis lurus.

Jika $3 x+2 y=16$ dan $2 x-y=-1$, maka nilai $x$ adalah $\ldots .$.
(a) 5
(c) $\frac{1}{2}$
(b) 2
(d) $\frac{5}{7}$

(Soal Matematika UM-PTKIN tahun 2019 nomor 27 dengan kode naskah 1911)

\section{Analisis Kalasifikasi Level Kognitif}

Hasil analisis soal matematika pada tes kemampuan dasar UM-PTKIN dikelompokkan menjadi 3 kategori pada level berpikir kognitif, yaitu Lower Order Thinking Skills (LOTS), Middle Order Thinking Skills (MOTS), dan Higher Order Thinking Skills (HOTS). Pada taksonomi Bloom revisi, suatu butir soal dikategorikan sebagai LOTS jika berada pada kategori mengingat, dikategorikan sebagai MOTS jika berada pada kategori memahami dan mengaplikasi, serta dikategorikan sebagai HOTS jika berada pada kategori menganalisis, mengevaluasi, dan mengkreasi.

Berdasarkan hal tersebut hasil analisis klasifikasi level kognitif soal matematika tes kemampuan dasar soal UM-PTKIN dengan kode naskah 1911 tahun 2019 berdasarkan Taksonomi Bloom Revisi disajikan pada Tabel 2. 
Tabel 2. Analisis Klasifikasi Level Kognitif Soal

\begin{tabular}{cccc}
\hline \hline Level Kognitif & Butir Soal & Jumlah & Persentasi \\
\hline C1 & 26 & 1 & $4 \%$ \\
C2 & $20,24,25,28,32,101$ & 6 & $22 \%$ \\
C3 & $22,23,27,29,30,31,33,34$ & 8 & $30 \%$ \\
C4 & $19,21,35,102,103,104$, & 9 & $33 \%$ \\
C5 & $107,108,109$ & 3 & $11 \%$ \\
C6 & $105,106,110$ & - & - \\
\hline Total & - & $\mathbf{2 7}$ & $\mathbf{1 0 0 \%}$ \\
\hline
\end{tabular}

Berdasarkan Tabel 2, soal matematika pada tes kemampuan dasar UM-PTKIN dengan kode naskah 1911 terdapat 1 butir soal (4\%) berada pada kategori LOTS atau pada level kognitif mengingat (C1), 14 butir soal (52\%) dengan kategori MOST dengan rincian 6 butir soal (22\%) pada level kognitif memahami (C2) dan 8 butir soal (30\%) pada level kognitif mengaplikasi (C3).Sedangkan, soal dengan kategori HOTS terdapat 12 butir soal (44\%) dimana soal terdiri dari 9 butir soal (33\%) level kognitif analisis (C4) dan 3 butir soal (11\%) level kognitif mengevaluasi (C5) serta tidak ditemukannnya soal dengan level mencipta (C6).

Level kognitif mengingat mengingat $(\mathrm{C} 1)$ merupakan kegiatan untuk mengingat (recall) kembali pengetahuan yang tersimpan dalam memori jangka panjang. Pada soal matematika UM-PTKIN tahun 2019 dengan kode naskah 1911, contoh soal pada level kognitif mengingat $(\mathrm{C} 1)$ terkait bilangan dapat dilihat pada soal seperti berikut:

Dibawah ini yang merupakan angka terjauh dari angka 1 pada garis bilangan adalah....
(a) -10
(c) 0
(b) -1
(d) 10

(Soal Matematika UM-PTKIN tahun 2019 dengan kode naskah 1911 No. 26 )

Pada soal tersebut menuntut peserta tes untuk mampu mengingat kembali materi pembelajaran terkait garis bilangan serta mengidentifikasi letak bilangan-bilangan yang terdapat pada pilihan jawaban. Pada level ini, kategori soal mudah namun tidak dapat sepelekan. Hal ini dikarenakan dalam menjawab soal membutuhkan kemampuan untuk menggali kembali rumus, peristiwa, defenisi maupun prosedur-prosedur dari penyelesaian soal.

Level kognitif memahami (C2) merupakan proses yang tidak hanya mengetahui namun mampu menafsirkan, menguasai, menangkap, mengartikan hingga menafsirkan makna dari suatu materi atau konsep. Anderson dan Krathwohl (2010) mendeskripsikan level kognitif taksonomi Bloom Memahami (C2) merupakan memahami (C2) merupakan proses mengkonstruksi baik menafsirkan, mencontohkan, 
mengklasifikasikan, merangkum, menyimpulkan, membandingkan, dan/atau menjelaskan makna dari suatu materi pembelajaran. Contoh soal pada level kognitif memahami (C2) yang menuntut kemampuan peserta tes untuk membedakan antara konstanta dan variabel serta mengklasifikasikannya sebelum melakukan operasi hitung, seperti berikut:

Jika $8-4 x=10 x+64$, maka nilai $x$ adalah
(a) -4
(c) 7
(b) -3
(d) 14

(Soal Matematika UM-PTKIN tahun 2019 dengan kode naskah 1911 No. 25 )

Proses berpikir menerapkan atau mengaplikasikan (C3) dimana karakteristik soal pada level ini menggunakan pengetahuan yang faktual, konsep dan prosedur-prosedur tertentu pada konsep lain dalam mata pelajaran yang sama maupun yang berbeda serta berorientasi dalam pemecahan masalah yang bersifat kontekstual. Bentuk soal level kognitif C3 dapat dilihat pada soal seperti berikut.

Nilai rata-rata ulangan Bahasa Inggris 40 siswa disuatu kelas adalah 7.8. Setelah satu orang siswa baru masuk dan mengukiti ulangan, nilai rata-rata ulangan Bahasa Inggris di kelas tersebut menjadi 7,85. Nilai ulangan Bahasa Inggris siswa baru adalah?
(a) 8,35
(c) 9,65
(b) 8,85
(d) 9,85

(Soal Matematika UM-PTKIN tahun 2019 dengan kode naskah 1911 No. 110 )

Soal tersebut menuntut kemampuan untuk mengidentifikasi komponenkomponen yang terdapat dalam soal dan memilih rumus yang akan digunakan sesuai dengan prosedur untuk menemukan solusi dari permasalahan. Kemampuan untuk mengingat rumus serta menerapkan prosedur dengan tepat merupakan langkah penyelesaian soal dengan kategori sedang atau sukar.

Proses berpikir analisis (C4) dimana karakteristik soal pada level ini menuntut peserta tes untuk memiliki daya nalar yang tinggi. Analisis mengharuskan siswa untuk melakukan pemeriksaan baik itu memilah, menguraikan, mengorganisir, membandingkan, merinci, atau mengklasifikasi data atau informasi yang kompleks menjadi sederhana dan saling berhubungan satu sama lain untuk memperoleh defenisi yang tepat dan mudah dipahami secara keseluruhan serta menemukan makna yang tersirat.

Level ini termasuk dalan kategori soal HOTS, dimana dalam menjawab soal mencakup penguasaan pada $\mathrm{C} 1$ hingga $\mathrm{C} 3$. Bentuk soal level kognitif $\mathrm{C} 4$ dapat dilihat pada soal seperti berikut.

Dua buah kapal laut bergerak lurus darisebuah pelabuhan dengan arah berbeda yang membentuk sudut $120^{\circ}$. Jika kapal A dan B masing-masing bergerak dengan 
kecepatan rata-rata $100 \mathrm{~km} / \mathrm{jam}$ dan $120 \mathrm{~km} / \mathrm{jam}$, maka jarak kedua kapal setelah menempuh perjalanan selama satu setengah jam adalah...
(a) $20 \sqrt{ } 91 \mathrm{~km}$
(c) $40 \sqrt{ } 91 \mathrm{~km}$
(b) $30 \sqrt{ } 91 \mathrm{~km}$
(d) $50 \sqrt{91} \mathrm{~km}$

(Soal Matematika UM-PTKIN tahun 2019 dengan kode naskah 1911 No. 120 )

Level berpikir evaluasi (C5) merupakan proses berpikir untuk mengambil dan menetapkan keputusan berdasarkan kriteria yang tepat. C5 menuntut kemampuan peserta didik untuk menyusun hipotesis, mengkritik, memprediksi, menilai, menguji, membenarkan atau menyalahkan. Sedangkan karakteristik soal pada level ini yakni soal membutuhkan penalaranan dan logika dalam pengambilan keputusan, memprediksi dan refleksi serta diperlukan suatu strategi dalam pemecahan masalah yang terkait dalam kehidupan sehari-hari atau bersifat kontekstual. Karakteristik soal level kognitif evaluasi (C5) dapat dilihat pada soal seperti berikut.

Diketahui bak mandi dengan ukuran panjang $80 \mathrm{~cm}$, lebar $55 \mathrm{~cm}$, dan tingginya $100 \mathrm{~cm}$. Sedangkan tangki berjari-jari $70 \mathrm{~cm}$ dan tingginya $100 \mathrm{~cm}$. Bak dan tangki tersebut diisi air hinggah penuh dengan menggunakan keran yang ukurannya berbeda. Bak mandi menggunakan keran dengan debit 400cm3/detik, sedangkan tangki dengan debit $700 \mathrm{~cm} 3 /$ detik. Jika keduanya diisi secara bersamaan, maka pernyataan dibawah ini yang tepat adalah...

(a) Bak mandi dan tangki penuh secara bersamaan

(b) Bak mandi dua kali lebih cepat penuh dibandingkan tangki

(c) Bak mandi empat kali lebih cepat penuh dibandingkan dengan tangki

(d) Bak mandi delapan kali lebih cepat penuh dibandingkan dengan tangki.

(Soal Matematika UM-PTKIN tahun 2019 kode naskah 1911 No. 110 )

Apabila ditinjau berdasarkan materi mata pelajaran matematika, ketersebaran soal pada tiap level dapat dilihat pada Tabel 3.

Tabel 3. Ketersebaran Soal Berdasarkan Materi

\begin{tabular}{clccc}
\hline \multirow{2}{*}{ No } & \multicolumn{1}{c}{ Materi } & \multicolumn{3}{c}{ Level Kognitif } \\
\cline { 2 - 5 } & & LOTS & MOTS & HOTS \\
\hline \hline 1 & Bilangan & 2 & & 1 \\
2 & Aritmetika Sosial & 1 & & 2 \\
3 & $\begin{array}{l}\text { Persamaan Linier satu dan } \\
\text { dua variabel }\end{array}$ & 2 & 1 & \\
4 & Perbandingan & & 1 & \\
5 & Statistik & & 1 & 1 \\
6 & Bangun datar & & 3 & 2 \\
7 & Himpunan & 1 & 1 & 1 \\
8 & Sudut & & & 1 \\
9 & Peluang & 1 & & 2 \\
10 & Trigonometri & & & 1 \\
11 & Turunan & & $\mathbf{8}$ & $\mathbf{1 2}$ \\
12 & Bangun ruang & $\mathbf{7}$ & \\
\hline & Total & & & \\
\hline & & & & \\
\hline
\end{tabular}


Berdasarkan Tabel 3 diketahui bahwa pada materi bilangan terdapat 2 soal LOTS dan 1 soal HOTS. Pada materi artmetika sosial terdapat 1 soal LOST dan 2 soal HOTS; pada materi sistem persamaan linier satu dan dua variabel terdapat 2 soal LOST dan 1 soal MOST; materi pebandingan terdapat 1 soal MOST; materi statistik terdapat 1 soal MOST dan 1 soal HOTS, pada materi bangun datar terdapat 3 soal MOST dan 2 soal HOTS, pada materi himpunan terdapat 1 soal MOST dan 1 soal HOTS, pada materi sudut terdapat 1 soal LOST, 1 soal MOST dan 1 soal HOTS; pada materi peluang terdapat 1 soal HOTS, pada materi trigonometri terdapat 1 soal LOST; pada materi turunan terdapat 2 soal HOTS dan pada materi bangun ruang terdapat 1 soal HOTS. Jika ditinjau dari materi secara keseluruhan, materi bangun datar merupakan materi yang paling banyak muncul dimana ketersebaran soal terdiri dari 3 soal MOST dan 2 Soal HOTS.

Berdasarkan hasil analisis, dalam pemecahan soal diatas diperlukan keterampilan mengorganisasi yang melibatkan proses pengindentifikasian hubungan antar informasi yang tersedia pada soal, menguraikan permasalahan dan menentukan bagaimana saling keterkaitan antar unsur-unsurnya serta penggunaan rumus yang tepat untuk menemukan solusi dari permasalahan yang disediakan. Secara keseluruhan, gambaran soal matematika UM-PTKIN tahun 2019 dengan kode naskah 1911 memuat 44\% soal HOTS yang memiliki kompleksitas yang tinggi dibandingkan soal lainnya. Selain itu, bentuk stimulus soal yang banyak muncul terdiri dari contoh dan penggalan kasus.

Gambaran soal matematika UM-PTKIN mampu menjadi pelajaran bagi siswa yang harus diketahui sebelum menghadapi seleksi. Kesiapan siswa tidak hanya pada soal-soal yang mengandalkan hafalan atau ingatan saja tetapi juga pada tingkatan soal yang lebih tinggi yang membutuhkan tingkat analisis, sintesis maupun evaluasi. Soal seperti ini merupakan sebagai bentuk latihan siswa dalam berpikir kritis dalam memecahkan masalah yang lebih kompleks sehingga ketika siswa telah masuk dalam jenjang pendidikan yang lebih tinggi, maka siswa siap menghadapi tantangan permasalahan yang lebih besar. Berpikir kritis menjadi keterampilan yang paling penting dalam menghadapi tantangan dan memecahkan masalah personal maupun sosial dikehidupan sehari-hari (Paringin, Mata dan Ipa, 2018; Sulistiani dan Masrukan, 2016).

\section{SIMPULAN}

Berdasasarkan hasil penelitian, dapat disimpulkan bahwa: 1) soal matematika pada tes kemampuan dasar UM-PTKIN tahun 2019 dengan kode naskah 1911 memuat 3 soal dengan bentuk stimulus gambar, 1 soal dengan bentuk stimulus grafik dan tabel, 3 soal dengan bentuk stimulusrumus, 2 soal dengan bentuk stimulus persamaan 
matematika, 4 soal dengan bentuk stimulus contoh serta 13 soal dengan bentuk stimulus penggalan kasus. 2) Soal memuat 26\% dengan kategori soal LOTS, 30\% dengan kategori soal MOST dan 44\% dengan kategori soal HOTS dengan ketersebaran materi soal secara keseluruhan, materi bangun datar merupakan materi yang paling banyak muncul.

Soal tipe Higher Order Thinking Skill (HOTS) merupakan soal-soal yang mengukur kemampuan berpikir tingkat tinggi siswa. Dengan pemberian latihan soal-soal HOTS ditingkat SD hingga menengah pada siswa maka akan mendukung tercapainya kemampuan literasi matematika siswa dalam level analisis, evaluasi, dan mengkreasi. Namun beberapa hal yang perlu diperhatikan dalam mpenyusunan soal HOTS yakni menyesuaikan materi maupun tingat kesukaran soal, serta penggunaan stimulus pada soal sebagai dasar siswa dalam menganalisis pertanyaan.

\section{REFERENSI}

Anderson, L. W., \& Krathwohl, D. R. (2001). Taxonomy for_Assessing a Revision of Bloom's Taxonomy of Educational Objectives. Addison Wesley Logman.Inc. (2010). Kerangka. Landasan. Untuk. Pembelajaran, Pengajaran, dan. Assesment. Diterjemahkan Oleh: A. Prihantoro. Pustaka Pelajar.

Arifin, Z. (2013). Evaluasi Pembelajaran. Bandung: PT. Remaja Rosdakarya Offset.

Merwe, D. V. D, \& Beer, M. D. (2006). Challenges of Student Selection : Predicting Academic Performance. South African Journal of Higher Education, 20(4): 547-562. https://journals.co.za/doi/10.10520/EJC37261

Brookhart, S. M. (2010). How to Assess Higher Order Thinking Skills in Your Classroom. ASCD.

Kemendikbud. Retrieved from Hardiknas 2018: Pendidikan Indonesia Butuh Penguatan High order thinking skills: https://www.kemdikbud.go.id/main/blog/2018/05/hardiknas-2018pendidikan-indonesia-butuh-penguatan-high-order-thinking-skills $\quad$ [diakses 15-4-2020]

Kurniati, D., Harimukti, R., \& Jamil, N. A. (2016). Kemampuan Berpikir Tingkat Tinggi Siswa SMP di Kabupaten Jember dalam Menyelesaikan Soal Berstandar Pisa. Jurnal Penelitian dan Evaluasi Pendidikan, 20(2): 142-155. https://doi.org/10.21831/pep.v20i2.8058

Lailly, N. R., \& Wisudawati, A. W. (2015). Analisis Soal Tipe Higher Order Thinking Skill ( HOTS ) dalam Soal UN Kimia SMA RAYON B Tahun 2012 / 2013. Kaunia, 11(1): 27-39. https://doi.org/http://dx.doi.org/10.14421/kaunia.1079 
Moleong, L. J. (2007). Metodologi Penelitian Kualitatif. Bandung: Remaja Rosdakarya.

Paringin, S., Mata, P., \& Ipa, P. (2018). Analisis Kemampuan Berpikir Kritis Siswa Kelas IX. Jurnal Pendidikan: Teori, Penelitian, dan Pengembangan, 3(2): $155-158$.

http://journal.um.ac.id/index.php/jptpp/article/view/10490/5163

Priatna, N., et al. (2017). Modul Pengembangan Keprofesian Berkelanjutan Mata Pelajaran Matematika Sekolah Menengah Pertama (SMP) Terintegrasi Penguatan Pendidikan Karakter. Jakarta: Direktorat Pembinaan Guru Pendidikan Dasar, Direktorat Jenderal Guru dan Tenaga Kependidikan Kemdikbud.

Prosedur Operasional Baku Ujian Masuk Perguruan Tinggi Keagamaan Islam Negeri, Panitia Nasional Penerimaan Mahasiswa Baru Perguruan Tinggi Keagamaan Islam Negeri Tahun 2020.

Santosa, A. B. (2013). Seleksi Calon Mahasiswa Baru Terhadap Kualitas Lulusan. Cakrawala Pendidikan, 16(11), 51-57.

Sulistiani, E., \& Masrukan. (2016). Pentingnya Berpikir Kritis dalam Pembelajaran Matematika untuk Menghadapi Tantangan MEA. Prosiding Seminar Nasional Matematika X Universitas Semarang 2016, 2017: Prosiding Seminar Nasional Matematika X 2016, 605-612. https://journal.unnes.ac.id/sju/index.php/prisma/article/view/21554/10278

Widana, I. W. (2017). Modul Penyusunan Soal Higher Order Thinking Skills. Jakarta: Direktorat Pembinaan SMA.

Witri, S., \& Tambunan, L. R. (2019). Deskripsi Kemampuan Berpikir Tingkat Tinggi Siswa dalam Menyelesaikan Soal Fungsi Kelas X SMAN 2 Tanjungpinang. Jurnal Gantang, 4(2): 155-160. https://doi.org/https://doi.org/10.31629/jg.v4i2.1527

Yenusi, T., Mumu, J., \& Tanujaya, B. (2019). Analisis Soal Latihan pada Buku Paket Matematika SMA yang Bersesuaian dengan Higher Order Thinking Skill. Journal of Honai Math, 2(1): 53-64. https://doi.org/10.30862/jhm.v2i1.58 